\title{
Lack of Evidence for Window Cancer of Healthy Adults Attending Low Standards Pharmacy Institutions in Pune
}

\author{
Rahul Hajare* \\ Post Doc Fellow, Indian Council of Medical Research New Delhi, India \\ Submission: July 14, 2018; Published: July 23, 2018 \\ *Corresponding author: Rahul Hajare, Post Doc Fellow, Indian Council of Medical Research New Delhi, India
}

Abstract

Cancer abuse has on the increase all over the world. The poor and the rich are also involved in this dangerous epidemic that has impact not only on reproductive health but also has an impact on family, society, increase in health care expense and increased depression activity. Health care providers have more concerned with treating the victims and less concerned on its prevention.

\section{Introduction}

Prevalence of window cancer infection with high risk behaviour in teaching staffs men women in remote rural areas of private pharmacy intuitions in reputed pune university Maharashtra State, India cannot ignore due poor sanitation and low level hygiene facility [1,2]. Organization and establishment of test center for evaluating health of teaching staffs with principal attending from long distance inconsistent residential mode. As a standard course of institutions, it would have got chemotherapy, which has no side effects. While the standard is detrimental at a primary stage, it can be no fatal if it comes back. It is able to do the test cheaper, reproducible and faster, helping institutions to customise the treatment for students. Over the years, incidences of cancer have spiked considerably, affecting millions of people worldwide. Out of the various types of cancers, high-grade cancers are those that are considered aggressive nature, as they spread rapidly particularly compared and modified alcohol dependent unsymmetrical teaching staffs. Metastasis has accepted as curable as the spread of cancer cells to other parts of the body, away from the primary area of formation (where it started) $[3,4]$. This occurs through the lymph system or through blood, which then forms tumours in other parts. These newlyformed tumours are called secondary tumours. «A metastasis often occurs in stage IV of different forms of cancer and is regarded as a serious or advanced stage, due to it being strong enough to spread to different parts of the body,» «The most common areas where metastasis develops are the liver window cancer, lungs, lymph nodes and bones. A person with lung cancer that has spread to the bones is said to have lung cancer with bone metastasis. In cases where the cancer has spread widely throughout the body even before it is diagnosed, on diagnosis if the area of origin remains unknown, it is known as cancer of unknown primary origin,» added unknown primary level standards. Treatment for metastatic cancer depends on the type of cancer, its place of origin of metastasis, the size of the tumour and other factors. Treatment typically aims at slowing down the growth and the spread zigzag. Treatment for these cancers requires systemic therapy that aims at reaching cancer cells at affected parts of the body through chemotherapy, hormonal therapy and immunotherapy [5,6]. Other types of therapies include radiation, biological therapy and surgery. "Serious illnesses that occur, especially suddenly, have the gravest effect on the mental health of the person diagnosed with the disease, as well as their family members. Dealing with the disease is the epitome of survival as it can weigh the strongest minds down,» Individual therapy helps a person address personal issues, talk to the therapist, follow council board regulation to avoid poor sanitation and identify the links between the illnesses. This therapy helps the person to change their self-depreciating thoughts and adapt and replace ways to evaluate their world.

Trauma therapy like eye movement desensitisation and reprocessing (EMDR) can also help in reducing anxiety associated with the illness. Therapies and psychiatric medication help in dealing with depression and anxiety that comes with the cancer $[7,8]$. They don't reduce the spread of cancer though. Family therapy is very important too. When in a self-depreciating zone, they require family and loved ones besides them to support and reassure them that everything is fine and would work out. Family could help them get better by speaking about the progress they 
show and how they are improving in terms of dealing with the illness when the patient themselves can't see it. «It is important that caregivers and family members also seek support as soon as diagnosis is drawn. Family members need to watch out for early signs or symptoms of emotional distress, anxiety and depression which may have a negative impact on the welfare of the teaching staffs. Support from family, friends and peers can permit the staffs to adjust better and instill a sense of hope. Meditation may be an appropriate solution to help soothe the nerves of both the patient and family members," The loss of a standard at private pharmacy institutors to breast cancer got by thinking and triggered this venture. Modern science is helping the medicine world create algorithms / models for precision medicine. If it can identify for a cancer patient, whether it's colon, breast or lung which medicines will be effective and which won't, it can tailor our treatment accordingly. This not just brings down costs and prevents avoidable side effects, it also helps in instituting the effective treatment options early, which should go on for survival benefit. The initial set of tests which have marketed have the first mover advantage, but are unfortunately exorbitantly priced, therefore, more than 98 per cent eligible patients are not benefiting from it. Standards, to your mind will disrupt this market and help bring down the cost, and, in the next couple of years these tests will be at $1 / 10$ th the cost. This will mean more reach and more than 10 -fold increase in this market space. It needs this for other cancers as well.

\section{Benefits of hydrotherapy in cancer}

People use hydrotherapy to treat many illnesses and conditions, including acne; arthritis; colds; depression; headaches; stomach problems; joint, muscle, and nerve problems; and stress. It can use for cancer therapy and to maintain health. It can also use hydrotherapy to reduce or relieve sudden stoke or long-lasting pain. Health benefits of hydrotherapy. Rehabilitates injured muscles: Being immersed in warm or hot water raises the body temperature, increasing blood flow around the circulatory system and so alleviating pain. The improved circulation will in turn help to heal injured cancer tissues and rehabilitate damaged muscles or cells cancerous.

\section{References}

1. Rahul Hajare (2018) Detection of High Addictive Habits Circulating Office in Charge of Private Pharmacy Institutions in Pune University India (Evidence Based Study of Late Report Office in Charge to College). Clinical Biotechnology and Microbiology 2(3): 377-381.

2. Rahul Hajare (2017) The Aggression is an Early Cause of Cancer. A Narrative Review of Classical to Modern Scientific Literature. Chronicle of Medicine and Surgery 1(2): 67-68.

3. Hajare R (2017) Can Otolaryngology Capture Window Cancer in Middle Adulthood? Ann Clin Lab Res 5(4): 205.

4. Rahul H (2018) Shocking Link of Rapid Rise in Pre-Cancer among the Healthy Adults in Pharmaceutical Institution Pune University India Living With Low Oxygen and Poor Sanitation Environment: Affordable Treatment Rate Three-Times Over. Glob J Add \& Rehab Med 5(5): 555673.

5. Rahul Hajare (2018) There is no Cure for the Cancer of Stupidity. Organic \& Medicinal Chem IJ 5(1): 555655.

6. Rahul Hajare (2018) An Attempt to Eradicate Alcohol Dependency from Adult Men in Service Privately Managed Pharmaceutical Institutions in India. Toxicology and Applied Pharmacology Insights 1(1): 180001.

7. Rahul H (2018) Shocking Link of Rapid Rise in Pre-Cancer among the Healthy Adults in Pharmaceutical Institution Pune University India Living with Low Oxygen and Poor Sanitation Environment: Affordable Treatment Rate Three-Times Over. Glob J Add \& Rehab Med 5(5): 555673.

8. Rahul A Hajare (2018) 909090 Formulas and Symptoms of Adrenal Fatigue Syndrome (AFS) of Adult Men. Orthop \& Spo Med Op Acc J 1(3).

\section{Your next submission with Juniper Publishers will reach you the below assets}

- Quality Editorial service

- Swift Peer Review

- Reprints availability

- E-prints Service

- Manuscript Podcast for convenient understanding

- Global attainment for your research

- Manuscript accessibility in different formats

( Pdf, E-pub, Full Text, Audio)

- Unceasing customer service

Track the below URL for one-step submission https://juniperpublishers.com/online-submission.php 